Louisiana State University LSU Digital Commons

Faculty Publications

Department of Geography \& Anthropology

2016

\title{
Cattle Colonialism: An Environmental History of the Conquest of California and Hawai'i
}

Andrew Sluyter

Louisiana State University, asluyter@lsu.edu

Follow this and additional works at: http://digitalcommons.lsu.edu/geoanth_pubs

Part of the Anthropology Commons, and the Geography Commons

\section{Recommended Citation}

Sluyter, Andrew, "Cattle Colonialism: An Environmental History of the Conquest of California and Hawai'i" (2016). Faculty Publications. 4.

http://digitalcommons.lsu.edu/geoanth_pubs/4

This Article is brought to you for free and open access by the Department of Geography \& Anthropology at LSU Digital Commons. It has been accepted for inclusion in Faculty Publications by an authorized administrator of LSU Digital Commons. For more information, please contact gcoste1@lsu.edu. 
with Franklin's 1768 articulation of civil liberty-which he conceived as personal dignity, economic independence, and political freedom inextricably linked to form a "common right" for all British citizens, including most importantly those living in far flung colonies (pp. x, 2).

Mulford takes on earlier historians' understandings of Franklin's political thought; she is never dismissive or critical of them but instead uses her skills as a literary critic to clarify and expand on what she understands as his ideology at key moments. She challenges those who believe that Franklin always articulated an ardent defense of American political rights in opposition to an overly powerful British Parliament as well as those who argue that Franklin became a passionate defender of American liberties only after Alexander Wedderburn's embarrassing denunciation of him before the British Privy Council (known as the "cockpit") in 1774. Drawing upon Franklin's published and unpublished papers, Mulford adamantly and consistently maintains that Franklin's early modern liberal notion of sovereignty was "not a new line of argument" for him but rather was an evolving, even maturing, ideology dating from Franklin family tales of political oppression throughout the English Civil War, becoming more fully developed in his 1750 letters to William Shirley, and reaching maturity in 1771 when he toured Ireland and finally understood the permanent damage an overweening power could do to the concept of individual rights grounded in the freedom of labor. Mulford turns a fresh analytical lens on Franklin's often-complicated critique of "the inconsistencies in a system that yoked imperialism to the language of liberalism while denying that any inherent rights and liberties belonged to those most valuable to the commonwealth, the laboring people" (p. 17). For Mulford, nowhere was this more evident than the British support of its eastern empire to the detriment of its American empire. That and not the "cockpit" debacle may have been the straw that broke the camel's back.

This is an otherwise-well-written book, but I do have one minor critique. I wish for a firmer connection between Franklin's political beliefs and his lived experiences as a successful
Philadelphian. For example, as Mulford highlighted Franklin's idealization of rural, independent landowners whose sovereignty rested on the labor theory of value, I wondered where the urban, urbane, and independently wealthy consummate consumer of material culture himself fit into his own political thought. Despite this reservation, I applaud Mulford for exploring Franklin's complicated and contradictory attitudes toward Native Americans and his shift from slave owner to late-in-life abolitionist (although I thought the suggestion that he did so because no servant would work with his wife an unfair and unconvincing argument).

Anyone who knows my work on Deborah Franklin and Sally Franklin Bache knows I am not a fan of Franklin the man, so it might be surprising to hear me say that Mulford's thorough and thoughtful analysis of his evolving intellectual commitment to American liberty has made me an admirer of Franklin the politician.

Vivian Bruce Conger
Ithaca College
Ithaca, New York

doi: 10.1093/jahist/jaw214

Cattle Colonialism: An Environmental History of the Conquest of California and Hawai' $i$. By John Ryan Fischer. (Chapel Hill: University of North Carolina Press, 2015. xiv, 266 pp. \$39.95.)

Several generations of scholars have demonstrated the fundamental role of cattle ranching in the colonization of the Americas and their environmental history. This book adds to that literature by comparing Californiaone of the key colonial ranching frontiers of North America - to the more peripheral, lessstudied Hawaii.

Rather than treating the two ranching frontiers sequentially, each chapter treats a particular theme relevant to both, revealing contrasts as well as many similarities and linkages. The first chapter details the introduction of cattle into each frontier over the late eighteenth century, by the Spaniards in California and the British in Hawaii, and those colonizers' paral- 
lel thinking regarding the civilizing role of livestock. The impacts on nature and native culture that followed form the theme of the next chapter, which oddly is titled "Landscapes" despite the section's distinct lack of use of the landscape concept, scarcity even of the word landscape, absence of maps to analyze transformation, and failure to engage the literature on landscape's material and discursive roles in colonialism.

While John Ryan Fischer makes brief assertions about the likely impacts of livestock on environment, his treatment of their impacts on native lifeways is somewhat more convincing, drawing on published correspondence of missionaries in eighteenth-century California and nineteenth-century Hawaii. Chapters 3 and 4 detail the ways Hawaii and California became major linked nodes in the livestock economy of an emerging Pacific world through the use of native labor and trade in livestock products, such as hides and tallow. The next chapter examines the hybrid ranching culture that emerged in parallel, especially when California cowboys began working in Hawaii in the 1830s. "Property," the final chapter, focuses on the apogee of cattle ranching during the nineteenth century, when new trade relationships, sources of capital, politics, and other factors resulted in the concentration of land in the hands of cattle barons.

This book thereby recasts Hawaii as an integral part of the American West rather than an exotic Pacific archipelago, and it will therefore be of interest mainly to historians of Hawaii. It would have been of broader interest had Fischer explicitly engaged relevant multidisciplinary literatures on the relationship between colonialism and landscape, problems of global environmental history, and ocean-centered approaches such as is done in Atlantic studies. Engaging such broad literatures would have also avoided serious mistakes, such as the assertion that cattle-ranching practices established in California and Hawaii derived exclusively from those of Iberia, ignoring African influences that were incorporated in the Atlantic world over the sixteenth and seventeenth centuries. Lassoing cattle from horseback, for example, a prominent practice in cattle herding in both California and Hawaii, is not an Iberian practice at all but was an innovation of cowboys of African origin in seventeenthcentury Mexico.

\author{
Andrew Sluyter \\ Louisiana State University \\ Baton Rouge, Louisiana
}

doi: 10.1093/jahist/jaw215

\section{Unruly Waters: A Social and Environmental} History of the Brazos River. By Kenna Lang Archer. (Albuquerque: University of New Mexico Press, 2015. xxviii, 260 pp. \$40.00.)

In this slim volume Kenna Lang Archer traces the history of water development schemes for the Brazos River of Texas between 1821 and 1890 . Using a wide variety of historical sources-including government documents, media reports, advertisements, and artwork-Archer chronicles various and competing projects that emerged in different times and places along the river.

Although Unruly Waters will be of interest mainly to those who study Texas history, it makes some useful claims about the broader history of American riparian development. Most notably, it argues that although different U.S. regions fostered divergent water development models, they shared a fundamental "technocratic conviction" during the nineteenth and twentieth centuries (p. xix). This argument is supported through detailed analysis of projects along different sections of the Brazos. The river's bottomlands on the humid Gulf Coast were targeted for navigation projects similar to those common throughout the American South and East, while its upper reaches in arid west Texas were marked for irrigation and flood control, as in other areas of the West. Despite frequent failures in both project approaches, however, Archer finds that boosters continually proposed bigger and more complex projects.

After an introductory chapter that focuses on the physical geography of the Brazos watershed, Archer's second chapter reviews changing cultural depictions of the river over time. She notes that Anglo-American artwork and texts first emphasized the "southern" characteristics of Brazos settlements (for example, manorial homes, cotton fields, slaves, and prison 